\title{
DIFFERENT TEMPERATURES AND SUBSTRATES ON Parkia platycephala Benth SEEDS GERMINATION
}

\author{
DIFERENTES TEMPERATURAS E SUBSTRATOS PARA GERMINAÇÃO DE \\ SEMENTES DE Parkia platycephala BENTH
}

\section{Edna Ursulino ALVES'; Magnólia Martins ALVES²; Rosemere dos Santos SILVA²; Luciana Rodrigues de ARAÚJO ${ }^{3}$; Flávio Ricardo da Silva CRUZ ${ }^{4}$; Maria de Lourdes dos Santos LIMA ${ }^{5}$}

1. Professora associada, Departamento de Fitotecnia e Ciências Ambientais, Centro de Ciências Agrárias, CCA - UFPB, Areia, PB, Brasil. ednaursulino@cca.ufpb.br; 2. Mestra em Agronomia pelo Programa de Pós-Graduação em Agronomia, Universidade Federal da Paraíba, UFPB, Areia, PB, Brasil; 3. Doutora em Agronomia, Universidade Federal da Paraíba, Areia, PB, Brasil; 4. Doutor em Agronomia, Universidade Federal da Paraíba, Areia, PB, Brasil; 5. Engenheira Agrônoma, Universidade Federal da Paraíba, UFPB, Areia, PB, Brasil.

\begin{abstract}
The faveira bean (Parkia platycephala Benth.), belongs to the Fabaceae family, this species is recommended for afforestation and also has a forage potential. In addition, it has the potential of landscaping, the wood can be used for box-office, tables for internal divisions in small constructions, linings, confection of toys, as well as for firewood and charcoal. That way, the aim of this study was to evaluate the effect of different temperature and substrate on the germination of seeds of $P$. platycephala. The study was carried out at the laboratory for analysis of Seeds of the Department of Plant Science and Environmental Agricultural Sciences Center of the da Universidade Federal da Paraíba, in Areia - PB. Therefore, a completely randomized design and a $6 \times 4$ factorial arrangement were performed, consisting of the combinations of six temperatures $\left(25,30\right.$ and $35{ }^{\circ} \mathrm{C}$ constant and 20-30, 20-35 and 25-35 ${ }^{\circ} \mathrm{C}$ alternating) and four substrates (sand, coconut fiber, paper and vermiculite). To evaluate the effect of the treatments were performed germination test, first count and germination speed index, length of plants, root and aerial dry matter. The constant temperature of $35^{\circ} \mathrm{C}$ provided better performance of seeds Parkia platycephala when using the sand as substrate.
\end{abstract}

KEYWORDS: Faveira. Forest species. Seed analysis. Vigor.

\section{INTRODUCTION}

Parkia platycephala Benth., belongs to the Fabaceae Family, popularly known as faveira, faveira-de-bolota, fava-de-bolota, visgueiro, favade-boi, sabiú, among others, occurring in the northeastern region of Brazil, in transition areas of Cerrado, Atlantic Forest and Caatinga, and also in the meadows of the Amazon region, which has potential for landscaping and forage, where the mature pods are a source of food supplementation for all ruminants, in addition to the wood uses, being used for construction of boxes, wooden boards for internal divisions in small constructions, linings, toys, as well as for energy purposes (LORENZI, 2009).

Seed germination, which comprises a sequence of physiological and biochemical events occurring before protrusion of the primary root into imbedded and non-dormant seeds until a normal seedling is obtained (MARCOS FILHO, 2005) is affected by internal factors, longevity and Viability, and external factors such as temperature, water and oxygen (CARVALHO; NAKAGAWA, 2012).

The temperature affects the percentage, speed and the uniformity of germination and is related to the biochemical processes (CARVALHO; NAKAGAWA, 2012), being an environmental factor that can interfere in the germinative capacity of seeds, in which the effects can also be evaluated from the changes on the germination rate (FONSECA; PEREZ, 1999).

For some species in the Fabaceae family, the germinative performance of the seeds is favored by constant temperatures, as example in Peltophorum dubium (Spreng.) Taub. (PEREIRA et al., 2013) and Guibourtia hymenaefolia (Moric.) (OLIVEIRA; PEREIRA, 2014), by alternating temperature, as in Caesalpinia pyramidalis Tul. (LIMA et al., 2011) and by insensitivity to the used temperature regime, as observed in the seeds of Parkia pendula (Willd.) Benth. Ex Walp. (ROSSETO et al., 2009).

The substrate is another factor that can also influence the germination process in several ways, where the choice of a substrate should be based on seed size and its requirement for moisture and light, especially by considering the its density, water absorption and retention capacity, aeration, drainage, absence of pests, diseases and toxic substances, in addition to promote an easy evaluation of seedlings (BRASIL, 2009). 
The interaction between the temperature and the substrate is important because the water retention capacity and the amount of light allowed by the substrate that reachs the seed can be responsible for different responses obtained within the same temperature (AGUIAR et al., 1993). With seeds of Caesalpinia pyramidalis Tul., Lima et al. (2011) obtained better germination at temperatures of $25,30,20-30$ and $20-35{ }^{\circ} \mathrm{C}$ in the sand substrate, as well as at $20-30$ and $20-35{ }^{\circ} \mathrm{C}$ in the vermiculite substrate, while the paper towel substrate in all temperatures impaired the germination.

Due to the importance of this species, informations regarding the germination test of its seeds are necessary for the knowledge of optimal conditions for conduction of germination tests. The aim of this study was to evaluate the influence of substrates and temperatures on the germination and vigor of $P$. platycephala seeds.

\section{MATERIAL AND METHODS}

The study was carried out at the laboratory for analysis of Seeds of the Department of Plant Science and Environmental Agricultural Sciences Center of the Universidade Federal da Paraíba, Areia, PB, with seeds of Parkia platycephala, mannually harvested, directly from the canopy of 15 matrix trees located in the same municipality.

After the harvesting, the fruits were manually threshed to extract the seeds, which were previously scarified with 80 Grit sandpaper in the opposite region to the yarn and treated with the fungicide Captan ${ }^{\circledR}$, at a concentration of $240 \mathrm{~g} / 100$ $\mathrm{kg}$ of seeds.

The germination test was conducted on germinators Biochemical Oxigen Demand (B.O.D.), regulated at constant temperatures of 25,30 and 35 ${ }^{\circ} \mathrm{C}$ and alternating temperatures from 20-30, 20-35 and $25-35{ }^{\circ} \mathrm{C}$, with eight-hour photoperiod in all temperatures using daylight fluorescent lamps $(4 \mathrm{x}$ $20 \mathrm{~W}$ ). For all treatments were used 100 seeds with four replicates of 25 seeds, distributed among the substrates of sand, coconut fiber and vermiculite, placed in transparent acrylic boxes (gerbox) with dimensions of $11 \times 11 \times 3.5 \mathrm{~cm}$; Paper towels (germitest ${ }^{\circledR}$ ) were also used (Brazil, 2009).

All substrates were previously sterilized by autoclaving for two hours at $120{ }^{\circ} \mathrm{C}$, for sand, fiber and vermiculite were adopted $60 \%$ water retention capacity used as the wetting standard, the paper roll was moistened with an amount of water equivalent to 2.5 times its dry weight.

The number of germinated seeds were evaluated daily, from three to eight days after sowing, using as a germination criteria the emergence of cotyledons and hypocoty. Germination percentage corresponded to the total percentage of germinated seeds until the eighth day after sowing, considering the normal seedlings, according to Brasil (2009).

The first counting germination test was carried out concurrently with the germination test, consisting of the normal seedling countings on the third day after sowing, and the results were expressed in percentage.

To determine the germination speed index (GSI) daily counts of normal seedlings were performed at the same time, from the third to the eighth day after sowing, and the index calculated using the formula proposed by Maguire (1962).

At the end of the germination test the length of the primary root and aerial part of the normal seedlings of each repetition was measured using a graduated ruler in centimeters, being the results expressed in centimeters. In order to determine the dry matter, the normal seedlings of each replicate were separated in roots and aerial parts and packed in Kraft paper bags and taken to a forced air circulation oven, regulated at $65{ }^{\circ} \mathrm{C}$, where they remained until reach a constant weight. The weighing of the dried material was carried out on a scale with an accuracy of $0.001 \mathrm{~g}$ and the results were expressed in milligrams (NAKAGAWA, 1999).

The analysis of variance of the experiment was performed according to a completely randomized experimental design, with the treatments distributed in a $6 \times 4$ factorial scheme (six temperatures and four substrates) in four replicates. The data were submitted to analysis of variance and the means grouped by the Scott-Knott test, at $5 \%$ probability.

\section{RESULTS AND DISCUSSION}

According to the results of the ANOVA (Table 2), temperature and substrate had significant effects on emergence, emergency speed index, first emergency count, root length and shoot, dry mass of roots and aerial part. 
Table 1. Mean squares referring to the germination percentage (G), first count (PC), germination speed index (IVG), root (CRA) and shoot length (CPA), roots (MSRA) and shoot dry mass (MSPA) of Parkia platycephala as a function under differents substrates and temperatures.

\begin{tabular}{|c|c|c|c|c|c|}
\hline$\overline{\mathrm{FV}}$ & GL & $\mathrm{G} \%$ & \multicolumn{2}{|l|}{$\mathrm{PC} \%$} & IVG\% \\
\hline TEMP & 5 & $5441.466667^{* *}$ & \multicolumn{2}{|c|}{$14471.100000^{* *}$} & $18.299750^{* *}$ \\
\hline SUBS & 3 & $1149.777778^{* *}$ & \multicolumn{2}{|l|}{$209.500000^{\mathrm{ns}}$} & $8.999794^{* *}$ \\
\hline TEMP*SUBST & 15 & $935.777778^{* *}$ & \multicolumn{2}{|l|}{$1845.233333^{\text {** }}$} & $1.936461^{* *}$ \\
\hline ERRO & 72 & 36.861111 & \multicolumn{2}{|l|}{45.583333} & 0.069181 \\
\hline CV (\%) & & 7.97 & \multirow{2}{*}{\multicolumn{2}{|c|}{$\begin{array}{l}12.19 \\
55.3750\end{array}$}} & 8.29 \\
\hline Média & & 76.1666 & & & 3.1712 \\
\hline$\overline{\mathrm{FV}}$ & $\overline{G L}$ & CRA (cm) & $\mathrm{CPA}(\mathrm{cm})$ & $\overline{M S R}(g)$ & $\operatorname{MSPA}(\mathrm{g})$ \\
\hline TEMP & 5 & $50.376101^{*}$ & $32.517070^{* * 3}$ & $0.000027^{\text {*** }}$ & $0.000964^{\text {*** }}$ \\
\hline SUBS & 3 & $2.767084^{* *}$ & $21.460861^{* *}$ & $0.000020^{* * *}$ & $0.000259^{* *}$ \\
\hline TEMP*SUBST & 15 & $5.110808^{* *}$ & $1.772101^{* *}$ & $0.000012^{\text {** }}$ & $0.000225^{* *}$ \\
\hline ERRO & 72 & 0.130898 & 0.120989 & 0.000003 & 0.000010 \\
\hline CV (\%) & & 8.10 & 8.06 & 30.38 & 16.15 \\
\hline Média & & 4.4657 & 4.3137 & 0.0053 & 0.0195 \\
\hline
\end{tabular}

${ }^{\text {ns }} \mathrm{e}^{* *}$ : não significativo e significativo a $1 \%$ de probabilidade pelo teste $\mathrm{F}$, respectivamente.

For all evaluated variables there was a significant effect between temperatures and substrates, with the highest germination percentage of Parkia platycephala seeds being observed in the combinations between the constant temperatures of $30{ }^{\circ} \mathrm{C}$ with the paper roll substrate and the temperature $35{ }^{\circ} \mathrm{C}$ in all of the used substrates, as well as at alternating temperatures of $20-30{ }^{\circ} \mathrm{C}$ in the the coconut fiber and vermiculite substrates and
25-35 ${ }^{\circ} \mathrm{C}$ in the coconut fiber and paper roll substrates (Table 1). Based on the obtained results, it can be affirmed that all the substrates can be used in the germination test, if combined with the appropriate temperature to provide optimal conditions for the germination of the seeds of this species and that the $P$. platycephala seedlings are capable of development under a wide temperature range.

Table 1. Germination (\%) of seeds of Parkia platycephala under differents substrates and temperatures.

\begin{tabular}{lcccccc}
\hline \multirow{2}{*}{ Substrates } & \multicolumn{7}{c}{ Temperatures $\left({ }^{\circ} \mathrm{C}\right)$} \\
\cline { 2 - 7 } & 25 & 30 & 35 & $20-30$ & $20-35$ & $25-35$ \\
\hline Sand & $73 \mathrm{aB}$ & $73 \mathrm{bB}$ & $88 \mathrm{aA}$ & $88 \mathrm{bA}$ & $57 \mathrm{bC}$ & $68 \mathrm{cB}$ \\
Coconut fiber & $46 \mathrm{bD}$ & $85 \mathrm{aB}$ & $92 \mathrm{aA}$ & $94 \mathrm{aA}$ & $60 \mathrm{bC}$ & $93 \mathrm{aA}$ \\
Paper roll & $00 \mathrm{cC}$ & $89 \mathrm{aA}$ & $92 \mathrm{aA}$ & $90 \mathrm{bA}$ & $48 \mathrm{cB}$ & $87 \mathrm{aA}$ \\
Vermiculite & $71 \mathrm{aD}$ & $88 \mathrm{aB}$ & $96 \mathrm{aA}$ & $97 \mathrm{aA}$ & $73 \mathrm{aD}$ & $80 \mathrm{bC}$ \\
\hline $\mathrm{CV}(\%)$ & \multicolumn{7}{c}{7.97} \\
\hline
\end{tabular}

Means followed by the same letter, lowercase in the column and upper case in the row, do not differ by a 5\% probability by the ScottKnott test.

Among the environmental factors, temperature and substrate are basic elements in the germination process, such as the physiological response variable in different temperatures and substrates, the influence of these components on the germination process may provide subsidies for the area of forest seed analysis (STOCKMAN et al. Al., 2007).

The vermiculite substrate at the temperature of $25^{\circ} \mathrm{C}$ provided higher germination percentages in Parapiptadenia rigida Benth seeds. (MONDO et al., 2008). For seeds of Caesalpinia pyramidalis Tul. the germination was higher at the temperatures of $30,20-30$ and $20-35^{\circ} \mathrm{C}$ in the sand substrate (LIMA et al., 2011). The vermiculite substrate at the temperature of $30{ }^{\circ} \mathrm{C}$ also provided a higher percentage of seed germination of Anadenanthera peregrina (L.) Speg. (MIRANDA et al., 2012), while for Mimosa caesalpiniifolia Benth. the highest percentages of germination occurred at the temperature of $30{ }^{\circ} \mathrm{C}$ on paper roll substrate (NOGUEIRA et al., 2013).

Similar to the data of the germination percentage of $P$. platycephala seeds, higher values 
were also observed in the first counting when the constant temperature of $30{ }^{\circ} \mathrm{C}$ was used with the coconut fiber substrate, $35{ }^{\circ} \mathrm{C}$ in all the substrates, and at the alternating temperature of $20-30{ }^{\circ} \mathrm{C}$ in the substrates coconut fiber, vermiculite and paper roll
(Table 2). According to that, it is verified that the higher temperatures favored the germination process of the seeds, possibly by accelerating the metabolic activities that culminate with the germination.

Table 2. First counting of seed germination of Parkia platycephala under different substrates and temperatures.

Substrates

Temperatures $\left({ }^{\circ} \mathrm{C}\right)$

\begin{tabular}{lcccccc} 
& 25 & 30 & 35 & $20-30$ & $20-35$ & $25-35$ \\
\hline Sand & $56 \mathrm{aC}$ & $75 \mathrm{bB}$ & $95 \mathrm{aA}$ & $43 \mathrm{bD}$ & $30 \mathrm{bE}$ & $20 \mathrm{cF}$ \\
Coconut fiber & $03 \mathrm{cC}$ & $85 \mathrm{aA}$ & $92 \mathrm{aA}$ & $86 \mathrm{aA}$ & $08 \mathrm{dC}$ & $41 \mathrm{bB}$ \\
Paper roll & $00 \mathrm{cE}$ & $75 \mathrm{bC}$ & $92 \mathrm{aA}$ & $83 \mathrm{aB}$ & $76 \mathrm{aC}$ & $20 \mathrm{cD}$ \\
Vermiculite & $18 \mathrm{bD}$ & $75 \mathrm{bB}$ & $92 \mathrm{aA}$ & $89 \mathrm{aA}$ & $19 \mathrm{cD}$ & $56 \mathrm{aC}$ \\
\hline
\end{tabular}

$\mathrm{CV}(\%)$

12.19

Means followed by the same letter, lowercase in the column and upper case in the row, do not differ by a $5 \%$ probability by the ScottKnott test.

The first counting germination test is important in determining the physiological quality of the seeds because it better expresses the vigor since all the normal seedlings emerged at the time of the first counting are considered the most vigorous (NAKAGAWA, 1999), the conditions of this test allow the seeds to germinate faster, ensuring the expression of their maximum physiological potential (BRASIL, 2009).

For Peltophorum dubium (Spreng) Taub., the highest percentages of germination at the first counting were obtained when Alves et al. (2011) used the substrate blotter paper in the temperatures of 20-30, 30 and $35{ }^{\circ} \mathrm{C}$. The highest percentages of germination of Dalbergia nigra (Vell.) Fr. All. seeds in the first counting occurred on the substrates of vermiculite, blotter paper and paper towel at 25 ${ }^{\circ} \mathrm{C}$ and Bioplant ${ }^{\circledR}$ and Plantmax ${ }^{\circledR}$ associated with temperature of $20-30{ }^{\circ} \mathrm{C}$ (GUEDES et al., 2011). In seeds of Clitoria fairchildiana Howard, the highest germination values in the first counting were also found at $30{ }^{\circ} \mathrm{C}$ in paper roll substrate (ALVES et al., 2013).

From the data on the germination speed index (GSI) of P. platycephala seeds (Table 3), it was verified that the highest values occurred only at the constant temperature of $35{ }^{\circ} \mathrm{C}$ in the sand substrate, indicating that the test is more sensitive in detecting the differences between the treatments and thus to better select the substrates and temperatures that should be recommended. According to Bewley and Black (1994), the temperature influences the capability and germination speed, affecting especially the rate of water absorption and the reactivation of the metabolic reactions, fundamental to the processes of reserve mobilization and the resumption of growth of the primary root.

Although for most species, the most favorable temperature for the germination of their seeds is between 26.5 and $35{ }^{\circ} \mathrm{C}$ (LOPES et al., 2005), the results obtained suggest that, for the germination of seeds, the highest temperature is obtained at a constant temperature of $35{ }^{\circ} \mathrm{C}$ (CARVALHO; NAKAGAWA, 2012). Guedes et al. (2011) found that in the seeds of Dalbergia nigra (Vell.) Fr. All., The highest rates of germination speed occurred at temperatures of $25{ }^{\circ} \mathrm{C}$ in all substrates tested (between sand, between vermiculite, bioplant ${ }^{\circledR}$, plantmax ${ }^{\circledR}$, Between and on paper and paper towel) and $20-30{ }^{\circ} \mathrm{C}$ on substrates between bioplant ${ }^{\circledR}$ and plantmax ${ }^{\circledR}$.

The highest average lengths of primary root were obtained in the temperature combinations of $30{ }^{\circ} \mathrm{C}$ in the paper roll substrate and $20-30{ }^{\circ} \mathrm{C}$ in the sand substrate, coconut fiber and vermiculite substrates (Table 4). These substrates provided higher length of seedlings, possibly meeting all requirements for a rapid germination as well as satisfactory initial growth (ALVES et al., 2008). 
Table 3. Germination speed index of Parkia platycephala seeds under different substrates and temperatures.

\begin{tabular}{lcccccc}
\hline \multirow{2}{*}{ Substrates } & \multicolumn{6}{c}{ Temperatures $\left({ }^{\circ} \mathrm{C}\right)$} \\
\cline { 2 - 7 } Sand & 25 & 30 & 35 & $20-30$ & $20-35$ & $25-35$ \\
Coconut fiber & $1,5 \mathrm{bD}$ & $3,0 \mathrm{aB}$ & $4,5 \mathrm{aA}$ & $3,6 \mathrm{bB}$ & $2,3 \mathrm{aC}$ & $3,4 \mathrm{aB}$ \\
Paper roll & $0,0 \mathrm{cE}$ & $3,0 \mathrm{bB}$ & $4,0 \mathrm{bA}$ & $3,0 \mathrm{cB}$ & $1,7 \mathrm{bD}$ & $2,9 \mathrm{aB}$ \\
Vermiculite & $2,0 \mathrm{bC}$ & $3,5 \mathrm{bB}$ & $4,5 \mathrm{bA}$ & $4,0 \mathrm{aB}$ & $2,7 \mathrm{aC}$ & $3,0 \mathrm{bC}$ \\
\hline
\end{tabular}

$\mathrm{CV}(\%)$

8.29

Means followed by the same letter, lowercase in the column and upper case in the row, do not differ by a 5\% probability by the ScottKnott test.

Table 4. Primary root length of Parkia platycephala seedlings originated of seeds under different substrates and temperatures.

Substrates

Temperatures $\left({ }^{\circ} \mathrm{C}\right)$

\begin{tabular}{lcccccc} 
& 25 & 30 & 35 & $20-30$ & $20-35$ & $25-35$ \\
\hline \multirow{2}{*}{ Sand } & $3,02 \mathrm{bC}$ & $4,94 \mathrm{~dB}$ & $3,39 \mathrm{aC}$ & $6,82 \mathrm{aA}$ & $3,11 \mathrm{bC}$ & $3,22 \mathrm{cC}$ \\
Coconut fiber & $4,40 \mathrm{aC}$ & $5,57 \mathrm{cB}$ & $2,74 \mathrm{bE}$ & $6,85 \mathrm{aA}$ & $3,72 \mathrm{aD}$ & $5,64 \mathrm{aB}$ \\
Paper roll & $0,00 \mathrm{cE}$ & $8,07 \mathrm{aA}$ & $2,49 \mathrm{bD}$ & $7,27 \mathrm{aB}$ & $2,88 \mathrm{bD}$ & $5,33 \mathrm{aC}$ \\
Vermiculite & $4,00 \mathrm{aC}$ & $6,41 \mathrm{bB}$ & $2,99 \mathrm{aE}$ & $7,05 \mathrm{aA}$ & $3,52 \mathrm{aD}$ & $4,05 \mathrm{bC}$ \\
\hline
\end{tabular}

$\mathrm{CV}(\%)$

8.10

Means followed by the same letter, lowercase in the column and upper case in the row, do not differ by a 5\% probability by the ScottKnott test.

The appropriate physical properties of coconut fiber make it an excellent substrate for seedlings development (DUARTE et al., 2010), as well as the high water retention capacity and the proper aeration conditions of vermiculite together with their physical properties, ss thickness and texture may have contributed to the increase of the root system of the seedlings (AZERÊDO et al., 2011).

For other forest species, such as Caesalpinia pyramidalis Tul. The longest length of seedlings was obtained in sand substrate at temperatures of $25,30,20-30$ and $20-35{ }^{\circ} \mathrm{C}$, as well as in vermiculite at the temperatures of 30, 20-30 and 20$35^{\circ} \mathrm{C}$ (LIMA et al., 2011).

The length of the aerial part (Table 5) was higher in the combinations of the temperature $30{ }^{\circ} \mathrm{C}$ in the substrate vermiculite, probably because the vermiculite substrate provides a greater aeration, which together with a more efficient degradation of the present reserves in the seeds, favored the development of the roots, since at this stage all seedling development is due to their chemical composition (BARROZO et al., 2014). When the seeds were sowed on the paper roll substrate, the shoot length obtained was longer $(4.77 \mathrm{~cm})$ at 35 ${ }^{\circ} \mathrm{C}$.

When the temperature is high, the speed of the biochemical reactions is accelerated, allowing a faster displacement of the nutritional reserves of the seed to the embryonic axis and photosynthetic substances necessary for the initial development of the aerial part (CARVALHO; NAKAGAWA, 2012). When the temperatures were observed isolated, it was observed a higher growth of $P$. platycephala seedlings when the seeds were 
submitted to the higher temperatures $\left(30{ }^{\circ} \mathrm{C}\right)$, and there were few satisfactory combinations in the interactions between the temperatures alternated with the substrates. For the initial development of $P$. platycephala seedlings, the temperature requirements are similar to those required in the first counting and germination speed, thus limiting the survival conditions of this species.

Table 5. Shoot length of seedlings Parkia platycephala from seeds under different substrates and temperatures.

Substrates

Temperatures $\left({ }^{\circ} \mathrm{C}\right)$

\begin{tabular}{lcccccc} 
& 25 & 30 & 35 & $20-30$ & $20-35$ & $25-35$ \\
\hline \multirow{2}{*}{ Sand } & $2,86 \mathrm{bD}$ & $6,58 \mathrm{bA}$ & $4,76 \mathrm{aC}$ & $5,02 \mathrm{bC}$ & $3,16 \mathrm{aD}$ & $5,57 \mathrm{aB}$ \\
Coconut fiber & $3,34 \mathrm{aD}$ & $6,27 \mathrm{bA}$ & $4,50 \mathrm{aC}$ & $5,72 \mathrm{aB}$ & $3,38 \mathrm{aD}$ & $5,38 \mathrm{aB}$ \\
Paper roll & $0,00 \mathrm{cD}$ & $4,62 \mathrm{cA}$ & $4,77 \mathrm{aA}$ & $3,50 \mathrm{cB}$ & $1,19 \mathrm{bC}$ & $3,35 \mathrm{bB}$ \\
Vermiculite & $3,66 \mathrm{aC}$ & $7,15 \mathrm{aA}$ & $3,96 \mathrm{bC}$ & $5,74 \mathrm{aB}$ & $3,36 \mathrm{aC}$ & $5,70 \mathrm{aB}$ \\
\hline
\end{tabular}

$\mathrm{CV}(\%)$

8.06

Means followed by the same letter, lowercase in the column and upper case in the row, do not differ by a 5\% probability by the ScottKnott test.

For the seedlings of Dalbergia nigra (Vell.) Fr. All., the highest lengths were obtained from seeds subjected to a temperature of $25{ }^{\circ} \mathrm{C}$ with substrates sand, plantmax ${ }^{\circledR}$ and paper towels and at a temperature of $20-30{ }^{\circ} \mathrm{C}$ with the bioplant ${ }^{\circledR}$ and plantmax ${ }^{\circledR}$ substrates (GUEDES et al., 2011).
The highest dry matter values of the seedlings roots were obtained when the seeds were submitted to a constant temperature of $30{ }^{\circ} \mathrm{C}$ in all substrates, except paper roll, at $20-30{ }^{\circ} \mathrm{C}$ in all substrates, except for coconut fiber and at the temperature of $25-35{ }^{\circ} \mathrm{C}$ on the paper roll substrate (Table 6).

Table 6. Dry matter of roots of Parkia platycephala seedlings from seeds under different substrates and temperatures.

\begin{tabular}{|c|c|c|c|c|c|c|}
\hline \multirow{2}{*}{ Substrates } & \multicolumn{6}{|c|}{ Temperatures $\left({ }^{\circ} \mathrm{C}\right)$} \\
\hline & 25 & 30 & 35 & $20-30$ & $20-35$ & $25-35$ \\
\hline Sand & $0,005 \mathrm{aD}$ & $0,008 \mathrm{aA}$ & $0,005 \mathrm{aD}$ & $0,008 \mathrm{aA}$ & $0,007 \mathrm{aB}$ & $0,006 \mathrm{aC}$ \\
\hline Coconut fiber & $0,004 \mathrm{bC}$ & $0,007 \mathrm{aA}$ & $0,006 \mathrm{aB}$ & $0,004 \mathrm{bC}$ & $0,003 \mathrm{bC}$ & $0,006 \mathrm{aB}$ \\
\hline Paper roll & $0,000 \mathrm{cD}$ & $0,003 \mathrm{bC}$ & $0,003 \mathrm{bC}$ & $0,008 \mathrm{aA}$ & $0,006 \mathrm{aB}$ & $0,007 \mathrm{aA}$ \\
\hline Vermiculite & $0,005 \mathrm{aB}$ & $0,007 \mathrm{aA}$ & $0,003 \mathrm{bC}$ & $0,008 \mathrm{aA}$ & $0,004 \mathrm{bC}$ & $0,005 \mathrm{bB}$ \\
\hline
\end{tabular}

Means followed by the same letter, lowercase in the column and upper case in the row, do not differ by a 5\% probability by the ScottKnott test.

The results show that, probably, there has been a greater transference of dry matter from the reserve tissues to the embryonic axis of the seeds, originating seedlings with greater weight, due to the greater accumulation of dry matter, which agrees with Custódio (2005).

For dry matter of the roots of the seedlings, are differences from those obtained by Guedes and Alves (2011), since they observed the highest dry 
matter values of the seedlings of Dalbergia nigra (Vell.) Fr. All., when the seeds were submitted at constant temperatures of 25 and $20-30{ }^{\circ} \mathrm{C}$ on substrates of sand, vermiculite and paper roll, as well as at $20-30{ }^{\circ} \mathrm{C}$ on the substrates bioplant ${ }^{\circledR}$ and plantmax ${ }^{\circledR}$. By the dry matter data of Caesalpinia pyramidalis Tul. in relation to the different substrates, it was observed that the sand favored a greater accumulation of dry matter in the seedlings at all temperatures of 25,30 and $20-35^{\circ} \mathrm{C}$ and paper towels at $25^{\circ} \mathrm{C}$ (LIMA et al. 2011).

The highest dry matter contents of $P$. platycephala seedlings occurred at temperatures of
$30{ }^{\circ} \mathrm{C}$ and vermiculite substrate, at $35{ }^{\circ} \mathrm{C}$ and sand substrate and at alternating temperature of $20-30{ }^{\circ} \mathrm{C}$ on the vermiculite substrate (Table 7 ). The dry matter content of Adenanthera pavonina $\mathrm{L}$. seedlings was not influenced by the different temperatures $\left(18,25,30\right.$ and $\left.20-30{ }^{\circ} \mathrm{C}\right)$ and substrates (paper roll and paper) (KISSMANN et al., 2007). The highest dry matter content of Piptadenia moniliformis Benth seedlings was obtained in those from the seeds submitted to the sand substrate at the temperature of $25{ }^{\circ} \mathrm{C}$ (AZERÊDO et al., 2011).

Table 7. Shoot dry matter of Parkia platycephala seedlings from seeds subjected to different substrates and temperatures.

\begin{tabular}{lcccccc}
\hline \multirow{2}{*}{ Substrates } & \multicolumn{5}{c}{ Temperatures $\left({ }^{\circ} \mathrm{C}\right)$} \\
\cline { 2 - 7 } & 25 & 30 & 35 & $20-30$ & $20-35$ & $25-35$ \\
\hline Sand & $0,010 \mathrm{bE}$ & $0,026 \mathrm{bC}$ & $0,039 \mathrm{aA}$ & $0,030 \mathrm{aB}$ & $0,011 \mathrm{aE}$ & $0,021 \mathrm{bD}$ \\
Coconut fiber & $0,017 \mathrm{aD}$ & $0,030 \mathrm{aB}$ & $0,033 \mathrm{bA}$ & $0,014 \mathrm{cE}$ & $0,012 \mathrm{aE}$ & $0,025 \mathrm{aC}$ \\
Paper roll & $0,00 \mathrm{cF}$ & $0,023 \mathrm{cB}$ & $0,029 \mathrm{cA}$ & $0,019 \mathrm{bC}$ & $0,009 \mathrm{aE}$ & $0,016 \mathrm{cD}$ \\
Vermiculite & $0,012 \mathrm{bC}$ & $0,029 \mathrm{aA}$ & $0,0057 \mathrm{dE}$ & $0,028 \mathrm{aA}$ & $0,009 \mathrm{aD}$ & $0,022 \mathrm{bB}$ \\
\hline
\end{tabular}

$\mathrm{CV}(\%)$

16.15

Means followed by the same letter, lowercase in the column and upper case in the row, do not differ by a 5\% probability by the ScottKnott test.

\section{CONCLUSION}

The sand substrate at the temperature of 35 ${ }^{\circ} \mathrm{C}$ is indicated for germination and vigor tests in seeds of Parkia platycephala.

RESUMO: A faveira (Parkia platycephala Benth.), pertence à família Fabaceae, é uma espécie recomendada para arborização e também possui potencial forrageiro. Além disso, tem potencial paisagístico, a madeira pode ser utilizada para caixotaria, tabuados para divisões internas em pequenas construções, forros, confecção de brinquedos, bem como para lenha e carvão. Dessa forma, o trabalho objetivou avaliar o efeito de diferentes temperaturas e substratos na germinação de sementes de $P$. platycephala. O mesmo foi realizado no Laboratório de Análise de Sementes, do Departamento de Fitotecnia e Ciências Ambientais do Centro de Ciências Agrárias da Universidade Federal da Paraíba, no município de Areia, PB. Portanto, realizou-se experimento em delineamento inteiramente ao acaso e arranjo fatorial $6 \times 4$, constituídos pelas combinações de seis temperaturas $\left(25,30\right.$ e $35{ }^{\circ} \mathrm{C}$ constantes e $20-30,20-35$ e $25-35{ }^{\circ} \mathrm{C}$ alternadas) e quatro substratos (areia, fibra de coco, papel e vermiculita). Para avaliação dos tratamentos realizou-se testes de germinação e vigor (primeira contagem e índice de velocidade de germinação, bem como o comprimento e massa seca das raízes e parte área). O substrato areia na temperatura de $35^{\circ} \mathrm{C}$ é recomendado para testes de germinação e vigor em sementes de Parkia platycephala.

PALAVRAS-CHAVE: Faveira. Espécie florestal. Análise de sementes. Vigor. 


\section{REFERENCES}

AGUIAR, I. B, PIÑA-RODRIGUES F. C. M, Figliolia MB. Sementes florestais tropicais. Brasília: ABRATES, 1993. 350p.

ALVES; E. U, GUEDES, R. S.; GONÇALVES, E. P.; VIANA, J. S.; SANTOS, S. S.; MOURA M F. Effect of temperature and substrate on germination of Peltophorum dubium (Sprengel) Taubert seeds. Acta Scientiarum. Biological Sciences, Maringá, v. 33, n. 1, p. 113-118, 2011. http://dx.doi.org/10.4025/actascibiolsci.v33i1.7057. Accessed em: 25 mar. 2017.

ALVES, M. M.; ALVES, E. U.; BRUNO, R. L. A.; SILVA, K. R. G.; BARROZO, L. M.; SANTOS-MOURA, S. S.; CARDOSO, E. A. Germinação e vigor de sementes de Clitoria fairchildiana Howard (Fabaceae) em função da coloração do tegumento e temperaturas. Bioscience Journal, Uberlândia, v. 29, n. 1, p. 216-223, 2013. http://www.seer.ufu.br/index.php/biosciencejournal/article/viewFile/13886/11990. Accessed em: 30 jun. 2017.

ALVES, E. U.; ANDRADE, L. A.; BARROS, H. H. A.; GONÇALVES, E. P.; ALVES, A. U.; GONÇALVES, G. S.; OLIVEIRA L. S. B.; CARDOSO E. A. Substratos para testes de emergência de plântulas e vigor de sementes de Erythrina velutina Willd., Fabaceae. Semina: Ciências Agrárias, Londrina, v. 29, n. 1, p. 69-82, 2008. http://dx.doi.org/10.1590/S0100-67622010000100007. Accessed em: 20 agost. 2017.

AZERÊDO, G. A.; PAULA, R. C.; VALERI, S. V. Temperatura e substrato para a germinação de sementes de Piptadenia moniliformis Benth. Scientia Forestalis, Piracicaba, v. 39, n. 92, p. 479-488, 2011.

http://www.ipef.br/publicacoes/scientia/nr92/cap11.pdf. Accessed em: 30 jun. 2017.

BARROZO, L. M.; ALVES, E. U.; SILVA, R. S.; ANJOS NETO, A. P.; SANTOS NETA, M. M. S.; SILVA, B. F. Substratos e temperaturas para testes de germinação e vigor de sementes de Inga laurina (Sw.) Willd.

Bioscience Journal, Uberlândia, v.30, n.1, p.252-261, 2014. www.seer.ufu.br/index.php/biosciencejournal/article/download/18037/14567. Accessed em: 13 jul. 2017.

BEWLEY, J. D.; BLACK M. Seeds: physiology of development and germination. New York: Plenum Press, 1994. 445p. https://doi.org/10.1007/978-1-4899-1002-8

BRASIL, Ministério da Agricultura, Pecuária e Abastecimento. Regras para análise de sementes. Secretaria de Defesa Agropecuária. Brasília: MAPA/ACS, 2009. 395p.

http://www.agricultura.gov.br/arq_editor/file/2946_regras_analise_sementes.pdf. Accessed em: 13 jul. 2017.

CARVALHO, N. M.; NAKAGAWA, J. Sementes: Ciência, tecnologia e produção. 5.ed. Jaboticabal: FUNEP, 2012. 590p.

CUSTÓDIO, C. C. Testes rápidos para avaliação do vigor de sementes: uma revisão. Colloquium Agrariae, v. 1, n. 1, p. 29-41, 2005.

http://www.scielo.br/scielo.php?script=sci_nlinks\&ref=000082\&pid=S01013122200800020002300003\&lng=p t. Accessed em: 13 jun. 2017.

DUARTE, R. F.; SAMPAIO, R. A.; BRANDÃO JÚNIOR, D. S.; FERNANDES, L. A.; SILVA, H. P. Crescimento inicial de Acácia em condicionador formado de fibra de coco e resíduo agregante. Revista Brasileira de Engenharia Agrícola e Ambiental, Campina Grande, v. 14, n. 11, p. 1176-1185, 2010. http://www.scielo.br/scielo.php?script=sci_arttext\&pid=S1415-43662010001100007. Accessed em: 13 jul. 2017.

FONSECA, S. C. L.; PEREZ, S. C. J. G. A. Efeito de sais e da temperatura na germinação de sementes de olho-de-dragão (Anadenanthera pavonina L. - Fabaceae). Revista Brasileira de Sementes, Londrina, v. 21, n. 2, p. 70-77, 1999. http://www.abrates.org.br/revista/artigos/1999/v21n2/artigo12.pdf. Accessed em: 30 jun. 2017. 
GUEDES, R. S.; ALVES, E. U. Germinação de sementes de Dalbergia nigra (Vell.) Fr. All. Acta

Scientiarum. Biological Sciences, Maringá, v. 33, n. 4, p. 445-450, 2011.

http://periodicos.uem.br/ojs/index.php/ActaSciBiolSci/article/viewFile/5834/5834. Accessed em: 30 jun. 2017.

KISSMANN, C.; SCALON, S. P. Q.; SCALON FILHO, H.; RIBEIRO, N. Tratamentos para quebra de dormência, temperaturas e substratos na germinação de Adenanthera pavonina L. Ciência e Agrotecnologia, Lavras, v. 32, n. 2, p. 668-674, 2007. http://dx.doi.org/10.1590/S1413-70542008000200051. Accessed em: 30 jun. 2017.

LIMA, C. R.; PACHECO, M. V, BRUNO, R. L. A.; FERRARI, C. S.; BRAGA JÚNIOR, J. M.; BEZERRA, A. K. D. Temperaturas e substratos na germinação de sementes de Caesalpinia pyramidalis Tul. Revista Brasileira de Sementes, Lavras, v. 33, n. 2, p. 216-222, 2011.

http://submission.scielo.br/index.php/jss/article/view/30086/6730. Accessed em: 28 jun. 2017.

LOPES, J. C.; CAPUCHO, M. T.; MARTINS FILHO, S, REPOSSI, P. A. Influência de temperatura, substrato e luz na germinação de sementes de bertalha. Revista Brasileira de Sementes, Pelotas, v. 27, n. 2, p. 18-24, 2005. http://www.scielo.br/scielo.php?script=sci_arttext\&pid=S010131222005000200004. Accessed em: 30 jun. 2017.

LORENZI, H. Árvores brasileiras: manual de identificação e cultivo de plantas arbóreas do Brasil. 3.ed. Nova Odessa: Instituto Plantarum, 2009. 368p. https://doi.org/10.1590/S0100-39842009000300014

MAGUIRE, J. D. Speed of germination aid in selection and evaluation for seedling emergence and vigor. Crop Science, Madison, v. 2, n. 2, p. 176-177, 1962. https://doi.org/10.2135/cropsci1962.0011183X000200020033x

MARCOS FILHO, J. Fisiologia de sementes de plantas cultivadas. Piracicaba: FEALQ, 2005. 495p.

MIRANDA, C. C.; SOUZA, D. M. S.; MANHONE, P. R.; OLIVEIRA, P. R.; BREIER, T. B. Germinação de Sementes de Anadenanthera peregrina (L.) Speg. com Diferentes Substratos em Condições Laboratoriais. Floresta e Ambiente, Rio de Janeiro, v. 19, n. 1, p. 26-31, 2012.

http://www.floram.org/articles/view/id/4ff2f3e61ef1faa37000000d. Accessed em: 30 jun. 2017.

MONDO, V. H. V.; BRACALION, P. H. S.; CICERO, S. M.; NOVEMBRE, A. D. L. C.; DOURADO NETO, D. Teste de germinação de sementes de Parapiptadenia rigida (Benth.) Brenan (Fabaceae). Revista Brasileira de Sementes, Lavras, v. 30, n. 2, p. 177-183, 2008. http://dx.doi.org/10.1590/S0101-31222008000200022. Accessed em: 30 jun. 2017.

NAKAGAWA J. Testes de vigor baseados no desempenho das plântulas. In: Krzyzanoski FC, VIEIRA RD, FRANÇA NETO JB. (Ed.). Vigor de sementes: conceitos e testes. Londrina: ABRATES, 1999. p. 2.1-2.24.

http://www.scielo.br/scielo.php?script=sci_arttext\&pid=S010131222008000200022. Accessed em: 30 jun. 2017.

NOGUEIRA, N. W.; RIBEIRO, M. C. C.; FREITAS, R. M. O.; GURGEL, G. B.; NASCIMENTO, I. L. Diferentes temperaturas e substratos para germinação de sementes de Mimosa caesalpiniifolia Benth. Revista de Ciências Agrárias, Belém, v. 56, n. 2, p. 95-98, 2013.

https://periodicos.ufra.edu.br/index.php?journal=ajaes\&page=article\&op=view\&path\%5B\%5D=872. Accessed em: 26 maio. 2017.

OLIVEIRA, A. K. M.; PEREIRA, K. C. L. Efeito de diferentes temperaturas na germinação e crescimento radicular de sementes de jatobá-mirim (Guibourtia hymenaefolia (Moric.) J. Léonard). Ciência Florestal, Santa Maria, v. 24, n. 1, p. 111-116, 2014. http://dx.doi.org/10.5902/1980509810538. Accessed em: 30 jun. 2017. 
PEREIRA, S. R.; KALIFE, C.; RODRIGUES, A. P. D. C.; LAURA, V. A. Influência da temperatura na germinação de sementes de Peltophorum dubium (Spreng.) Taub. Informativo ABRATES, Londrina, v. 23, n. 3, p. 52-55, 2013. http://www.abrates.org.br/images/Informativo/v23_n3/07.pdf. Accessed em: 30 jun. 2017.

ROSSETO, J.; ALBUQUERQUE, M. C. F.; RONDON NETO, R. M.; SILVA, I. C.O. Germinação de sementes de Parkia pendula (Willd.) Benth. ex Walp. (Fabaceae) em diferentes temperaturas. Revista Árvore, Viçosa, v. 33, n. 1, p. 47-55, 2009. http://www.scielo.br/scielo.php?script=sci_arttext\&pid=S010067622009000100006. Accessed em: 30 jun. 2017.

STOCKMAN, A. L.; BRANCALION, P. H. S.; NOVEMBRE, A. D. L. C.; CHAMMA, H. M. C. P. Sementes de ipê-branco (Tabebuia roseo-alba (Ridl.) Sand.-Bignoniaceae): temperatura e substrato para o teste de germinação. Revista Brasileira de Sementes. Lavras, v. 29, n. 3, p. 139-143, 2007.

http://www.scielo.br/scielo.php?script=sci_arttext\&pid=S0101-31222007000300016. Accessed em: 30 jun. 2017. 